\title{
Insulin-like growth factors-I and -II and insulin-like growth factor-binding protein-2 in dominant equine follicles during spring transition and the ovulatory season
}

\author{
E D Watson, S-E Bae, R Thomassen, S R M Thomson, K Woad ${ }^{1}$ and D G Armstrong ${ }^{1}$ \\ Department of Veterinary Clinical Studies, University of Edinburgh, Easter Bush, Roslin, Midlothian EH25 9RG, \\ UK and ${ }^{1}$ Division of Integrative Biology, Roslin Institute (Edinburgh), Midlothian EH25 9PS, UK
}

Correspondence should be addressed to Elaine Watson; Email: Elaine.Watson@ed.ac.uk

\begin{abstract}
The period between seasonal anoestrus and cyclicity is characterized in many mares by cyclical growth and regression of large dominant follicles. The insulin-like growth factor (IGF) system plays a key role in follicular growth and regression; therefore, we hypothesized that changes in the IGF system and its binding proteins would modulate onset of cyclicity in mares. Ovaries were obtained from pony mares on the day after detection of an actively growing $30 \mathrm{~mm}$ transitional anovulatory follicle, and also at the second or third oestrus of the breeding season on the day after the preovulatory follicle reached $30 \mathrm{~mm}$ in diameter. Size of dominant follicles at the time of removal was similar in transition $(32 \pm 0.8 \mathrm{~mm})$ and at oestrus $(34 \pm 0.6 \mathrm{~mm})$. IGF-I mRNA was present in granulosa cells, with low thecal expression, whereas IGF-II mRNA was confined to the theca layer. Expression of IGF-I and -II mRNAs, and intrafollicular concentrations of oestradiol, were lower $(P<0.01$; paired $t$ test) in transitional anovulatory follicles than in preovulatory follicles. Messenger RNA encoding IGFBP-2 was present in both theca and granulosa layers. Steady-state concentrations of mRNA encoding IGFBP-2 mRNA increased $(P<0.001)$ in theca in preovulatory follicles. Intrafollicular concentrations of IGFBP-2 were higher $(P<0.001)$ in transitional than in preovulatory follicles. The similarity in circulating concentrations of IGF-I in transitional and cyclic mares, suggested that the somatotrophic axis is not involved in transition from anovulatory to ovulatory cycles. The results suggest that the increased expression of IGF-I and -II mRNAs in preovulatory follicles, along with the decrease in IGFBP-2 concentrations, could increase the bioavailability of intrafollicular IGF in large follicles during the breeding season, and support our hypothesis that intrafollicular IGF bioavailability must exceed a threshold level before ovulation can occur.

Reproduction (2004) 128 321-329
\end{abstract}

\section{Introduction}

Mares are seasonally polyoestrus, and frequently there is cessation of cyclical ovarian activity in autumn as day length decreases. In early spring, the period of transition between anoestrus and cyclicity is characterized by a resurgence of follicular activity, irregular exhibition of oestrous behaviour and resumption of secretion of gonadotrophins and ovarian steroids (Ginther 1990, Davis \& Sharp 1991). During spring transition, in many mares, large follicles grow sequentially in the ovaries to a size similar to preovulatory follicles and then regress without ovulating (Ginther 1990, Watson et al. 2002a). These large follicles are steroidogenically incompetent, produce significantly lower concentrations of oestradiol and progesterone than preovulatory follicles within the natural breeding season, and have significantly lower expression of mRNA encoding key steroidogenic enzymes (Davis \& Sharp 1991, Watson et al. 2002b, 2004).

Growth factors, in particular the insulin-like growth factor (IGF) system, are thought to play a key role in ovarian follicular growth and atresia (Armstrong et al. 2000). The IGFs have a variety of effects on follicular and luteal cells, including stimulation of steroidogenesis, via increased availability of steroid precursors and upregulation of steroidogenic enzyme expression and activity. Follicular concentrations of IGF-I increase in large equine follicles (Bridges et al. 2002), whereas IGF-II concentrations are not different among different sizes of follicle. It has been suggested that intrafollicular IGF-I may be involved in selection of dominant follicles in mares (Donadeu \& Ginther 2002, Ginther et al. 2002). 
IGF-binding proteins (IGFBPs) present within the ovary bind with IGFs, prolonging the half-life, but blocking the biological action of the IGFs (for review see Armstrong \& Webb 1997). Follicular concentrations of IGFBP-2, -4 and -5 decrease during follicular growth and increase during atresia in most species, including horses (Spicer \& Echternkamp 1995, Gerard \& Monget 1998). In contrast, levels of IGFBP-3 remain constant (Stewart et al. 1996, Gerard \& Monget 1998). In large, oestrogen-active equine follicles, the relative proportion of IGF:IGFBP was twofold greater than in other follicle types, indicating that the increase in bioavailable IGF may play a key role in promoting follicular maturation (Bridges et al. 2002).

It is known that circulating concentrations of growth hormone $(\mathrm{GH})$ in mares are higher during the ovulatory season than during winter anoestrus (Aurich et al. 1999). GH mediates many of its effects through IGF-I (Spicer \& Echternkamp 1995), and it is apparently via this mechanism that $\mathrm{GH}$ alters ovarian function. Systemic administration of $\mathrm{GH}$ raises plasma concentrations of IGF-I in a number of species, including horses (Owen et al. 1991, Spicer et al. 1992, Buonomo et al. 1996). We hypothesized that the bioavailability of IGF would be lower during spring transition, when follicles grow to preovulatory size but fail to ovulate, contributing to failure of normal follicular steroidogenesis and development at this time. In order to investigate this hypothesis, various components of the IGF system were studied in large dominant follicles obtained from transitional and cyclic mares.

\section{Materials and Methods}

We used 15 pony mares aged 3-20 years and weighing $270-400 \mathrm{~kg}$. From mid-February, the ovaries were examined three times per week by transrectal ultrasonography. In March to early April, when a follicle appeared that was greater than $25 \mathrm{~mm}$, the mares were examined daily and the ovary containing the large follicle was removed on the day after it reached $30 \mathrm{~mm}$ in diameter. The contralateral ovary was removed at the second $(n=5)$ or third $(n=10)$ oestrus after the onset of cyclicity on the day after the largest follicle reached $30 \mathrm{~mm}$. The ovary was placed on ice and transported to the laboratory. Follicular fluid was collected by needle aspiration and stored at $-20^{\circ} \mathrm{C}$. Sections of follicle wall from eight of the mares, when they were in spring transition and cycling, were placed in optimal temperature cutting medium (Miles Inc, Elkhart, IN, USA) on cork discs and snap frozen in an isopentane/dry ice slurry. The samples were then stored at $-70^{\circ} \mathrm{C}$. Immediately prior to ovariectomy, a jugular blood sample was collected into an evacuated heparinized tube. The plasma was removed after centrifugation and stored at $-20^{\circ} \mathrm{C}$. Plasma samples were available from all 15 mares, but in three of the mares, the dominant follicle ruptured at the time of ovariectomy and so no follicular fluid was available. The study was performed under the approval of the University of Edinburgh Animal Ethics Committee, and the project licence was obtained under the Home Office Animals (Scientific Procedures) Act 1986.

\section{Western ligand blot}

The IGFBPs in follicular fluid were analysed by onedimensional SDS-PAGE, as described previously (Nicholas et al. 2002). Samples $(15 \mu \mathrm{l})$ were heat denatured in Tris-glycine SDS buffer $\left(5 \mathrm{~min}\right.$ at $\left.100^{\circ} \mathrm{C}\right)$, and then fractionated on $4 \%$ stacking/ $12 \%$ resolving SDS-PAGE gels $(8.6 \times 6.8 \mathrm{~cm}$ Mini-Protean III system; Bio-Rad, Hercules, CA, USA) at a constant current $(125 \mathrm{~V})$ for $2 \mathrm{~h}$ under non-reducing conditions. The proteins were electroblotted onto a PVDF membrane for $1.5 \mathrm{~h}$ at room temperature. After rinsing of the membrane and initial blocking with $3 \%(\mathrm{w} / \mathrm{v})$ BSA in PBS-0.1\% (v/v) Tween 20, the membrane was incubated overnight at $4{ }^{\circ} \mathrm{C}$ with biotinylated IGF-II. On the next day, the membrane was washed and the solution was replaced with $20 \mathrm{ml}$ of a 1:4000 dilution of extravidin-peroxidase in blocking solution. After incubation for $5 \mathrm{~min}$ and further washing, the signal was detected with the ECL-plus system on hyperfilm-ECL film, and developed using an automated system (X-Ograph) with an exposure time of $3 \mathrm{~min}$. The band densities were quantitated using Quantity One Control and Analysis Software for a Fluor-S Scanning System (Bio-Rad Laboratories Ltd, Hemel Hempstead, UK).

\section{In situ hybridization}

Plasmids containing cDNAs for bovine IGFBP-2, IGF-I and IGF-II were linearized as described previously (Armstrong et al. 1998). Antisense and sense $\left[{ }^{35} \mathrm{~S}\right] \cup T P$-labelled cRNA probes were transcribed from these templates with a transcription kit (Promega Ltd, Southampton, UK) according to the manufacturer's instructions. Purification of the cRNA probes was by centrifugation on a Sephadex G-50 column. The bovine cDNA sequences for IGF-I and IGF-II are $93 \%$ and $90 \%$ homologous with those of the horse. Equine IGFBP-2 cDNA has not been sequenced to our knowledge, but homology is greater than $90 \%$ in all species tested to date.

Sections $(14 \mu \mathrm{m})$ were cut from each of the frozen tissue samples. Sections ( $n=3$ of each sample) were dehydrated, fixed and probed with the appropriate ${ }^{35}$ S-labelled riboprobes for IGFBP-2, IGF-I and IGF-II, by the method described by $\mathrm{Xu}$ et al. (1995). After the final high-stringency wash, the sections were dehydrated through a graded series of alcohols, air dried, dipped in autoradiographic K2 photographic emulsion (Ilford Ltd, Mobberley, UK) and exposed for up to 2 weeks at $4{ }^{\circ} \mathrm{C}$. Sections were then developed (Kodak D-19; IBI Limited, Cambridge, UK) and fixed (Hypam fix, Ilford Ltd) before staining with haematoxylin and eosin. The sections were finally mounted in DPX mountant (BDH Laboratories, Poole, UK), before microscopic examination, using both light- and dark-field illumination. The antisense RNA probes were hybridized to two of the sections, and the 
remaining slide was hybridized with the corresponding sense RNA probes.

\section{Quantitation of grain density}

The intensity of the in situ hybridization signal was measured by an $\mathrm{NIH}$-image analysis system $(\mathrm{NIH}$, Bethesda, MD, USA). The number of graphic pixels occupied by silver grains (identified by a set grey threshold) within a defined area of the tissue section was counted and presented as a percentage of the total pixel number within the defined area. Background hybridization intensity, measured with the sense RNA probes, was subtracted from the measurements obtained with antisense probes to give the final hybridization signal. For each follicle, three separate fields were analysed for each probe. There was no significant difference $(P>0.05)$ in hybridization intensity obtained with antisense and sense RNA probes within a non-expressing region of a tissue section. Under the conditions described here, the hybridization signal was proportional to the length of time the slides were exposed to photographic emulsion (for up to 2 weeks).

\section{Oestradiol assay}

Concentrations of oestradiol-17 $\beta$ were measured directly in follicular fluid by assays described previously (Glasier et al. 1989, Watson et al. 2002b). Intra- and interassay coefficients of variation were 4.6 and $7.8 \%$. Assay sensitivity was $8 \mathrm{pg} / \mathrm{ml}$, and displacement curves from serial dilutions of follicular fluid, and curves produced by addition of hormone to follicular fluid were parallel to the respective standard curve.

\section{IGF-I assay}

Concentrations of IGF-I were measured in follicular fluid and plasma by RIA after extraction using high-performance liquid chromatography (Gutierrez et al. 1997) to remove IGFBPs. The limit of detection of the assay was $23 \mathrm{pg}$. The intra-assay coefficient of variation was $7 \%$. All samples were included in the same assay.

\section{Statistical analyses}

Differences in the steady-state concentrations of mRNAs between pairs of follicles (transitional versus preovulatory, and granulosa versus theca) and follicular fluid concentrations of components of the IGF system, within mares, were analysed by paired $t$-test. Differences in IGFBP-2 band densities were analysed using the OD figure generated by Quantity One Software. Correlations were analysed by Pearson's correlation test. Hormone concentrations in samples collected at ovariectomy were compared by paired $t$-test. Differences were considered to be significant when $P<0.05$. Means are quoted \pm S.E.M.

\section{Results}

\section{Follicle size and health}

Size of the dominant follicle at removal $(n=15$ per group) was not different in transition $(32 \pm 0.8 \mathrm{~mm})$ or cyclicity $(34 \pm 0.6 \mathrm{~mm})$. Size of follicle was not significantly different at the second $(n=5 ; 33 \pm 0.9 \mathrm{~mm})$ or third $(n=10 ; 34 \pm 1.6 \mathrm{~mm}$ ) oestrus. Histological examination of the follicle walls confirmed than none of the follicles were atretic at time of removal according to the criteria of Kenney et al. (1979).

\section{Concentrations of oestradiol, IGF-I and IGFBP-2 in follicular fluid from preovulatory and transitional follicles}

Concentrations of oestradiol were higher $(P<0.001)$ in follicles collected during cyclicity than during transition (Table 1). There were no differences in oestradiol concentrations between follicles collected at second or third oestrus $(1171 \pm 274.5$ vs $1725 \pm 367.0 \mathrm{ng} / \mathrm{ml}$ respectively). Follicular IGF-I concentrations did not differ between transition and cyclicity (Table 1), and were not correlated with follicular oestradiol concentrations.

Ligand blotting with biotinylated IGF-II identified bands of $40-44 \mathrm{kDa}$ (IGFBP-3) and $34 \mathrm{kDa}$ (IGFBP-2; Fig. 1). When IGF-II $(1 \mu \mathrm{g})$ was added along with biotinylated IGF-II to the membranes, all the bands identified as IGFBP-2 and -3 disappeared. Concentrations of IGFBP-2 were $4.3 \pm 1.12$-fold higher $(P<0.001)$ in fluid from transitional follicles than in fluid from preovulatory follicles (Fig. 1).

\section{Concentration of oestradiol and IGF-I in plasma from mares during spring transition and the breeding season}

Plasma oestradiol concentrations were lower $(P<0.01)$ in transitional than in cyclic mares (Table 1). There were no differences in plasma concentrations of IGF-1 between transition and cyclicity (Table 1). Plasma concentrations of IGF-I were not affected by age of the mare $(3-20$ years; Pearson correlation $=-0.433 ; P>0.05$ ).

Concentrations of IGF-I were higher in plasma than in follicular fluid $(P<0.05$; Table 1$)$, and did not differ between cyclicity and transition. There was a positive

Table 1 Concentrations (mean \pm S.E.M.) of IGF-I and oestradiol in mares in spring transition and the ovulatory season.

\begin{tabular}{lcc}
\hline & Oestradiol & IGF-I \\
\hline Follicular concentrations $n=12$ & $\mathbf{( n g} / \mathbf{m l})$ & $\mathbf{( n g} / \mathbf{m l})$ \\
Transition & $801 \pm 120^{\mathrm{a}}$ & $209 \pm 31^{\mathrm{c}}$ \\
Cyclicity & $2057 \pm 416^{\mathrm{a}}$ & $224 \pm 20^{\mathrm{d}}$ \\
Plasma concentrations $n=15$ & $(\mathbf{p g} / \mathbf{m l})$ & $(\mathbf{n g} / \mathbf{m l})$ \\
Transition & $2.8 \pm 0.4^{\mathrm{b}}$ & $422 \pm 20^{\mathrm{c}}$ \\
Cyclicity & $18.1 \pm 4.5^{\mathrm{b}}$ & $428 \pm 30^{\mathrm{d}}$ \\
\hline
\end{tabular}

${ }^{\mathrm{a}} P<0.001 ;{ }^{\mathrm{b}} P<0.01 ;{ }^{\mathrm{c}} P<0.05 ;{ }^{\mathrm{d}} P<0.05$. 


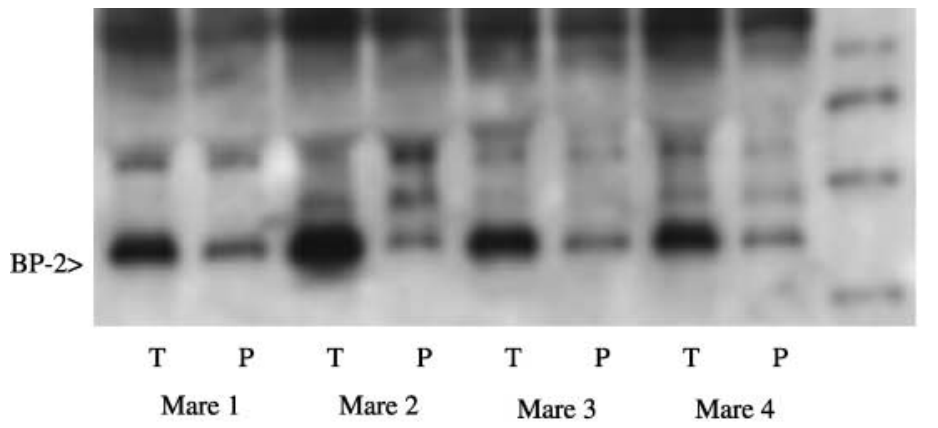

$60 \mathrm{KDa}$

$50 \mathrm{KDa}$

$40 \mathrm{KDa}$

$30 \mathrm{KDa}$

expression in preovulatory follicles compared with transitional follicles, whereas expression in granulosa remained unchanged (Fig. 6).

\section{Discussion}

In the present study, circulating and follicular concentrations of IGF-I were not different in transitional and cyclic mares, indicating that endocrine control by hepatic derived IGF-I is not involved in transition to cyclicity in mares. However, the increased expression of IGF mRNAs in preovulatory follicles, combined with the decrease measured in IGFBP-2 concentrations in follicular fluid, will increase the bioavailability of IGF compared with transitional follicles, an effect which may be critical in determining ovulatory potential of the follicles.

In a previous study, pony mares first ovulated at a median date of 3 May (E D Watson, unpublished data); therefore, the first ovary of these mares was removed at least 1 month before this. The low concentrations of oestradiol in follicular fluid from the follicles collected in transition, and in plasma from transitional mares, confirm that these follicles were correctly identified and that potential preovulatory follicles were not removed in error. The mares in the present study were hemi-ovariectomized prior to onset of ovarian cyclicity. In a previous study, we confirmed that removal of one ovary during transition did not

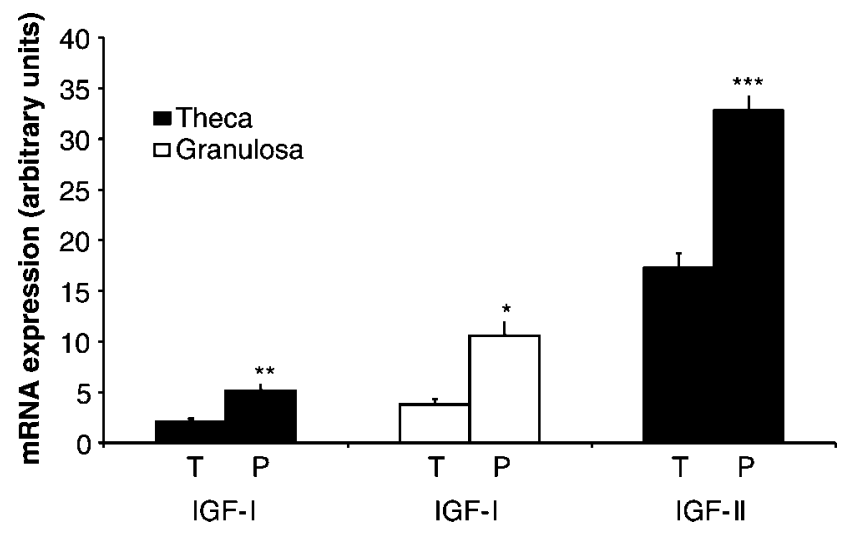

Figure 3 Expression of mRNAs (mean \pm S.E.M.) in granulosa and theca encoding IGF-I and IGF-II in transitional $(\mathrm{T})$ and preovulatory $(\mathrm{P})$ follicles. $* P<0.05 ; * * P<0.01 ; * * * P<0.001$.
Figure 2 Bright-field ( $a$ ) and dark-field (b and c) illumination of an IGF-I cRNA. T and G represent granulosa and theca tissue respectively. Bar represents $100 \mu \mathrm{m}$. 

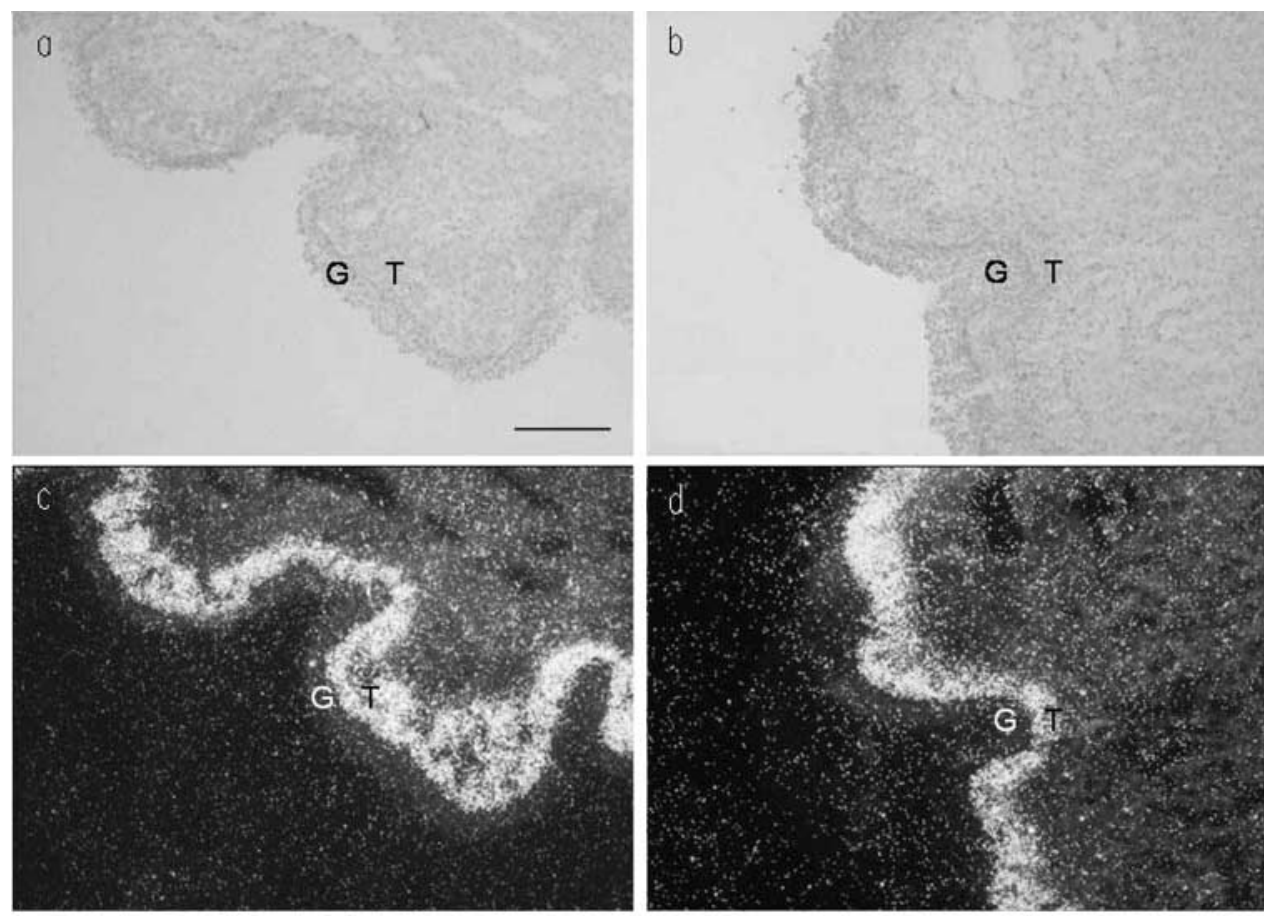

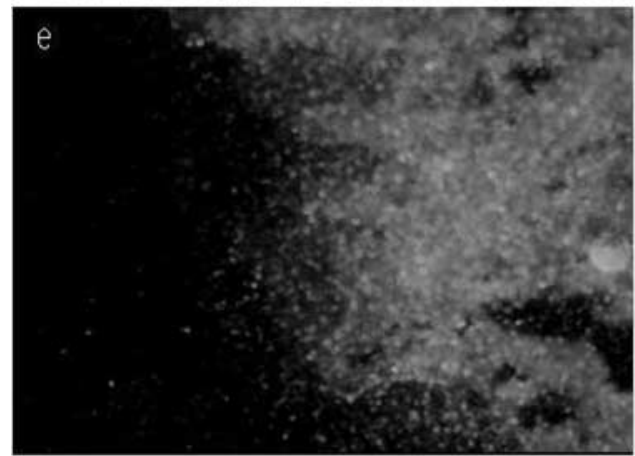

Preovulatory follicle

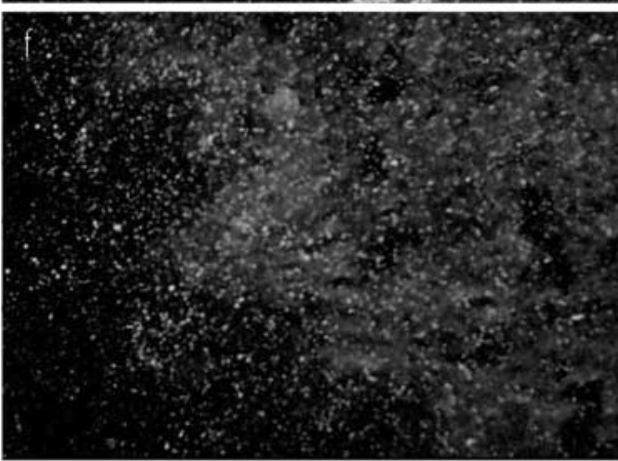

Transitional follicle

Figure 4 Bright-field ( $a$ and b) and dark-field images of preovulatory ( $a, c$ and e) and transitional (b, d and f) follicles probed with either antisense (c and d) or sense (e and f) cRNAs for IGF-II. (G) Granulosa layer; (T) theca layer. Scale bar represents $100 \mu \mathrm{m}$.

affect circulating concentrations of luteinizing hormone, follicle-stimulating hormone or oestradiol, or follicle growth during the ovulatory season compared with mares with two ovaries (Watson et al. 2004). Therefore, it is unlikely that removal of one ovary in the present study had any influence on follicular function in the remaining ovary.

The spatial distribution and expression of mRNAs encoding IGF-I and -II in follicles appears to be speciesspecific (Armstrong \& Webb 1997). We have shown that mRNA encoding IGF-I is present in equine granulosa cells and, to a lesser extent, theca cells. In this respect, the horse may differ from other species. In rodents, pigs and women, the expression of mRNA encoding IGF-I is confined to granulosa cells (Armstrong \& Webb 1997), and is only detectable in very low amounts in ruminant follicles (Perks et al. 1999, Armstrong et al. 2000). Messenger RNA encoding IGF-II was detected only in theca cells in the present study, in a spatial distribution similar to that reported in sheep, rats, pigs and cows (Armstrong \& Webb 1997, Armstrong et al. 2000).

Intrafollicular concentrations of IGF-I, but not IGF-II, have been positively correlated with follicle size in mares (Spicer et al. 1991, Bridges et al. 2002), and concentrations of IGF-I are higher in follicles that assume dominance (Ginther et al. 2002). However, in other species, the presence of a correlation between follicle development and intrafollicular IGF-I has been less clear (for review see Monget et al. 2002), and this is thought to be due to differences in the efficiency of extraction of IGF-I. In the present study, IGF-I concentrations were measured in follicular fluid after acid gel filtration. Traditional extraction methods, such as solvent extraction, fail to remove all of the IGFBPs (Gutierrez et al. 1997); therefore, this is the first report of the measurement of total IGF-I concentrations in equine follicular fluid in which possible inaccuracies due to the presence of IGFBPs in the assay 

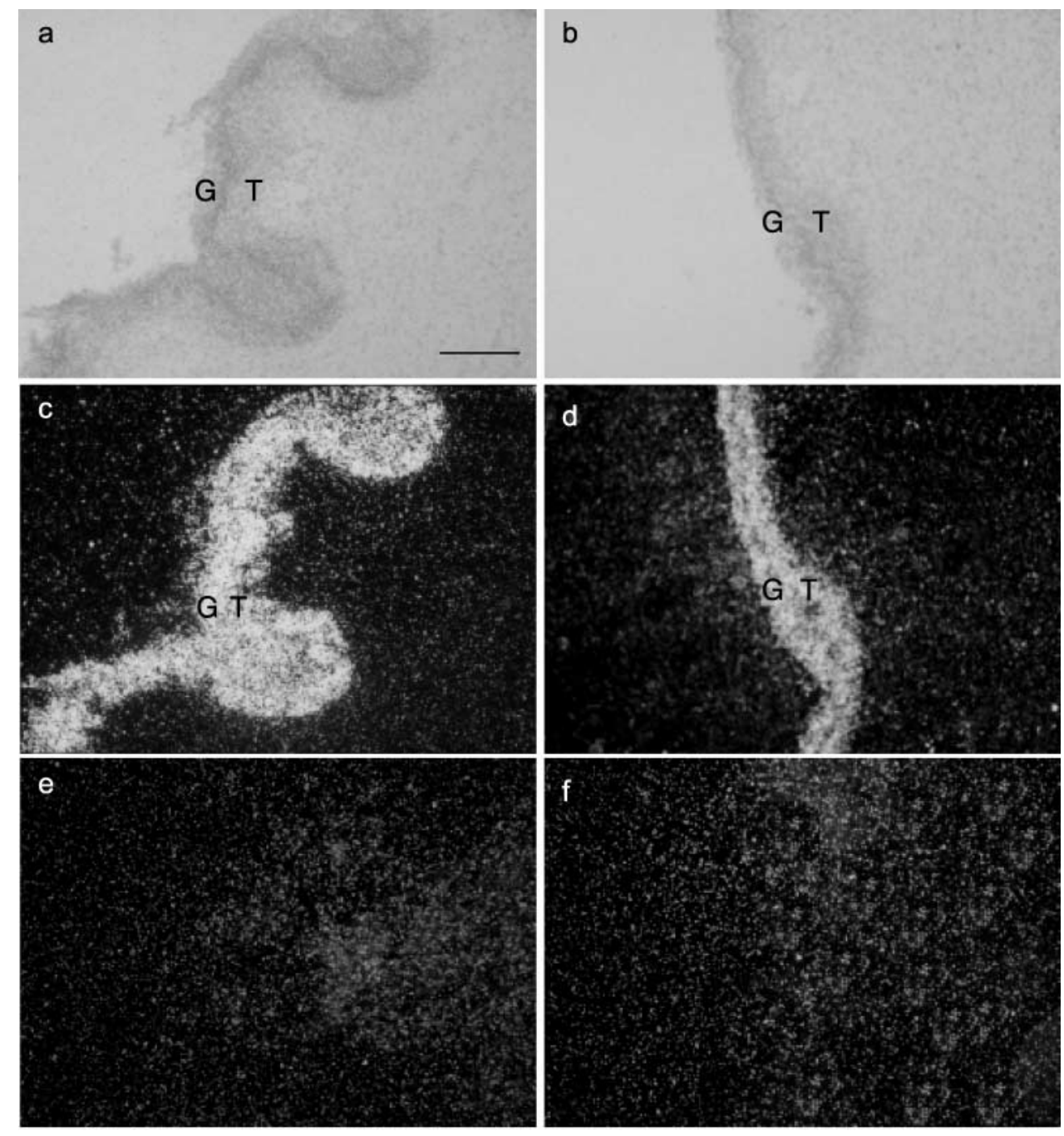

Preovulatory follicle

Transitional follicle

Figure 5 Bright-field ( $a$ and b) and dark-field images of preovulatory ( $a, c$ and e) and transitional (b, $d$ and f) follicles probed with either antisense (c and d) or sense (e and f) cRNAs for IGFBP-2. (G) Granulosa layer; (T) theca layer. Scale bar represents $100 \mu \mathrm{m}$.

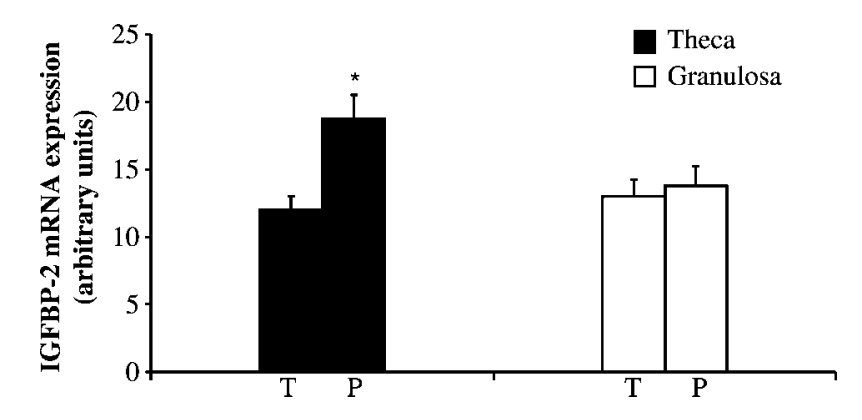

Figure 6 Expression of mRNAs (mean \pm S.E.M.) in granulosa and theca encoding IGFBP-2 in transitional $(\mathrm{T})$ and preovulatory $(\mathrm{P})$ follicles. mRNA for IGFBP-2 was expressed in the granulosa and theca. $* P<0.05$. have been eliminated. However, in previous studies, the differences in IGF-I levels in different follicle types were small. Despite the identification of IGF-I mRNA in equine follicle walls in the present study, expression was low. Our results concur with those of Spicer and co-workers (1991), who reported that the main source of IGF-I in equine follicles is serum. This was confirmed in the present study by the higher plasma concentrations, and the highly significant correlation between plasma and follicular concentrations in cyclic mares. The lack of correlation in transitional mares probably reflects the lower vascularity of transitional follicles (Watson \& Al-zi'abi 2002). We conclude therefore that the changes seen in expression of IGF-I mRNA in transitional and cyclic follicles may have little effect on its intrafollicular concentrations, because of the high levels present in serum. By contrast, the high level of expression of IGF-II mRNA in equine follicles in the present study, along with the observation that equine 
granulosa cells produce $10-50$-fold more IGF-II than IGFI in culture (Davidson et al. 2002), indicates that IGF-II is the major intrafollicular form of IGF ligand in the mare. There is discrepancy between the absence of mRNA encoding IGF-II from granulosa cells in the present study, and the production of IGF-II by cultured equine granulosa cells (Davidson et al. 2002). However, it is possible that some minor thecal contamination of the cultures may have accounted for IGF-II synthesis.

$\mathrm{GH}$ is a key regulator of circulating IGF-I concentrations and influences hepatic expression of IGF-I mRNA (O'Sullivan et al. 2002). Plasma IGF-I concentrations were increased in mares treated with equine somatotrophin, showing that a similar relationship exists in the horse (Cochran et al. 1999). GH concentrations are reported to be higher in mares during the breeding season than during winter anoestrus (Aurich et al. 1999), a finding which might suggest that IGF-I concentrations should be stimulated during the breeding season. However, this latter study did not differentiate between deep winter anoestrus and spring transition. It is possible that increases in $\mathrm{GH}$ and IGF-I concentrations precede spring transition, and are the stimulus for growth of the large transitional anovulatory follicles. The similarity in plasma IGF-I concentrations in transitional and cyclic mares suggests that changes in the somatotrophic axis are not involved in the transition from anovulatory to ovulatory cycles. A direct effect of GH on the ovary cannot, however, be excluded, and it is possible that the decreased expression of IGF-I mRNA in dominant follicles in transitional mares results from inadequate $\mathrm{GH}$ stimulation.

There was a wide age range in the mares in the present study, four of the mares being only 3 years old. It is thought that IGF-I and IGFBPs modulate growth in horses (Malinowski et al. 1996). However, in our study, age of the mare was not correlated with circulating IGF-I concentration, probably because adult size had almost been achieved.

In other domestic species, changes in IGFBP concentrations are more closely associated with follicle growth and regression than are changes in levels of IGF-I and -II (Spicer \& Echternkamp 1995, Stewart et al. 1996), because only free IGF has biological activity. Furthermore, it has recently been shown that IGFBPs can directly inhibit steroidogenesis (Wright et al. 2002). In cyclic mares, intrafollicular levels of IGFBP-2, -4 and -5 decrease in large, oestrogenically active dominant follicles compared with subordinate follicles or large regressing follicles, which contain only low concentrations of oestrogen (Gerard \& Monget 1998, Bridges et al. 2002). Therefore, it has been proposed that follicular levels of these binding proteins are closely related to the physiological status of equine follicles. Changes in these IGFBPs are probably regulated through changes in gene transcription and/or proteolysis (Rajarm et al. 1997). Levels of the IGFBPs in follicular fluid depend not only on synthesis, but also on degradation by proteases. In equine follicular fluid, there is little or no proteolysis of IGFBP-2 and -3; therefore, it was suggested that levels of these IGFBPs directly represent production (Bridges et al. 2002). However, IGFBP-4 and IGFBP-5 protease activity has been found in preovulatory equine follicles (Mazerbourg et al. 2000, Bridges et al. 2002), and therefore intrafollicular levels of these IGFBPs represent synthesis plus degradation.

It is reported that incubated granulosa cells from mares produce IGFBP-2 and -5 (Davidson et al. 2002); however, there has been no information on the presence or location of mRNA encoding the IGFBPs in equine follicles. In the present study, IGFBP-2 mRNA was located in both granulosa and theca layers, in contrast to the cow and sheep, where IGFBP-2 mRNA is confined to granulosa cells (Besnard et al. 1996, Armstrong et al. 1998), but similarly to the pig (Yuan et al. 1996) and women (Zhou \& Bondy 1993).

In the present study, levels of IGFBP-2 were approximately fourfold lower in preovulatory follicles than in transitional follicles, despite the increased thecal expression of IGFBP-2 mRNA in preovulatory follicles. In contrast to the mare, in the cow and sheep the decrease in levels of IGFBP-2 during follicle growth is due largely to a loss of expression of mRNA encoding IGFBP-2 in the granulosa cells of dominant follicles (Besnard et al. 1996, Armstrong et al. 1998). One explanation of the discrepancy between message and protein in the mare would be the presence of IGFBP-2 protease activity in follicular fluid of preovulatory follicles. In the ewe and sow, there is increased IGFBP-2 proteolysis during follicle growth (Monget et al. 2002). However, earlier work has suggested that equine follicular fluid does not contain IGFBP-2 proteolytic activity (Bridges et al. 2002).

Subordinate or large regressing follicles with low concentrations of oestrogen are characterized by higher levels of IGFBP-2, -4 and -5 than are preovulatory follicles (Gerard \& Monget 1998). The large transitional anovulatory follicles in the present study similarly contained higher levels of IGFBP-2 than preovulatory follicles, even though histological examination of transitional anovulatory follicles collected in the present study showed that they were healthy and did not have features associated with atresia (Kenney et al. 1979). The high levels of IGFBP-2 in transitional follicles would be expected to decrease IGF bioavailability in these follicles, and so contribute to the steroidogenic inadequacy of these follicles.

In conclusion, we have shown that expression of mRNAs encoding IGF-I and -II is greater in preovulatory follicles that are destined to ovulate than in large follicles collected during spring transition. Although expression of mRNAs encoding IGFBPs was similar, or even higher, in preovulatory follicles, intrafollicular concentrations of IGFBP-2 were lower in preovulatory follicles. The increased expression of IGF-I and -II in preovulatory follicles, coupled with decreased concentration of IGFBP2 , could increase intrafollicular IGF bioavailability in 
preovulatory follicles, compared with anovulatory follicles, and so contribute to the increased steroidogenesis and subsequent ovulation of these follicles.

\section{Acknowledgements}

This study was supported by the Horserace Betting Levy Board (project number 666). The authors are grateful to Shirley Melling for assistance with the research mares.

\section{References}

Armstrong DG \& Webb R 1997 Ovarian follicular dominance: the role of intraovarian growth factors and novel proteins. Reviews of Reproduction 2 139-146.

Armstrong DG, Baxter G, Gutierrez CG, Hogg CO, Galzyrin AL, Campbell BK, Bramley TA \& Webb R 1998 Insulin-like growth factor binding protein-2 and -4 messenger ribonucleic acid expression in bovine ovarian follicles: effect of gonadotropins and developmental status. Endocrinology $1392146-2154$.

Armstrong DG, Gutierrez CG, Baxter G, Glazyrin AL, Mann GE, Woad KJ, Hogg CO \& Webb R 2000 Expression of mRNA encoding IGF-I, IGF-II and type 1 IGF receptor in bovine ovarian follicles. Journal of Endocrinology $165101-113$.

Aurich C, Gerlach T, Aurich JE \& Parviz N 1999 Seasonal variation and opioidergic regulation of growth hormone release in cyclic, ovariectomized, and pregnant pony mares. Biology of Reproduction 61 1575-1580.

Besnard N, Pisselet C, Monniaux D, Locatelliu A, Benne F, Gasser F, Hatey F \& Monget P 1996 Expression of messenger ribonucleic acids of insulin-like growth factor binding proteins-2, -4 and -5 in the ovine ovary: localization and changes during growth and atresia of antral follicles. Biology of Reproduction $\mathbf{5 5}$ 1356-1367.

Bridges TS, Davidson TR, Chamberlain CS, Geisert RD \& Spicer LJ 2002 Changes in follicular fluid steroids, insulin-like growth factors (IGF) and IGF-binding protein concentration, and proteolytic activity during equine follicular development. Journal of Animal Science 80 179-190.

Buonomo FC, Ruffin DS, Bremendeuhl JP, Veenhuizen JJ \& Sartin JL 1996 The effects of bovine somatotropin (bST) and porcine somatotropin (pST) on growth factor and metabolic variables in horses. Journal of Animal Science 74 886-894.

Cochran RA, Leonardi-Cattolica AA, Sullivan MR, Kincaid LA, Leise BS, Thompson Jr DL \& Godke RA 1996 The effects of equine somatotropin (eST) on follicular development and circulating plasma hormone profiles in cyclic mares treated during different stages of the estrous cycle. Domestic Animal Endocrinology 16 57-67.

Davidson TR, Chamberlain CS, Bridges TS \& Spicer LJ 2002 Effect of follicle size on in vitro production of steroids and insulin-like growth factor (IGF)-I, IGF-II, and the IGF-binding proteins by equine ovarian granulosa cells. Biology of Reproduction $\mathbf{6 6}$ 1640-1648.

Davis SD \& Sharp DC 1991 Intra-follicular and peripheral steroid characteristics during vernal transition in the pony mare. Journal of Reproduction and Fertility Supplement 44 333-340.

Donadeu FX \& Ginther OJ 2002 Changes in concentrations of follicular fluid factors during follicle selection in mares. Biology of Reproduction 66 1111-1118.

Gerard N \& Monget P 1998 Intrafollicular insulin-like growth factorbinding protein levels in equine ovarian follicles during preovulatory maturation and regression. Biology of Reproduction $\mathbf{5 8}$ 1508-1514.

Ginther OJ 1990 Folliculogenesis during the transitional period and early ovulatory season in the mare. Journal of Reproduction and Fertility 90 311-320.
Ginther OJ, Meira C, Beg MA \& Bergfelt DR 2002 Follicle and endocrine dynamics during experimental follicle deviation in mares. Biology of Reproduction 67 862-867.

Glasier AF, Irvine DS, Wickings EJ, Hillier SG \& Baird DT 1989 A comparison of the effects on follicular development between clomiphene citrate, its two isomers, and spontaneous cycles. Human Reproduction 4 252-256.

Gutierrez CG, Campbell BK, Armstrong DG \& Webb R 1997 Insulinlike growth factor-I (IGF-I) production by bovine granulosa cells in vitro and peripheral IGF-I measurement in cattle serum: an evaluation of IGFBP extraction protocols. Journal of Endocrinology $153231-240$.

Kenney RM, Condon W, Ganjam VK \& Channing C 1979 Morphological and biochemical correlates of equine ovarian follicles as a function of their state of viability or atresia. Journal of Reproduction and Fertility Supplement 27 163-171.

Malinowski K, Christensen RA, Hafs HD \& Scanes CG 1996 Age and breed differences in thyroid hormones, insulin-like growth factor (IGF)-1 and IGF binding proteins in female horses. Journal of Animal Science 74 1936-1942.

Mazerbourg S, Zapf J, Bar RS, Brigstock DR \& Monget P 2000 Insulin-like growth factor (IGF)-binding protein-4 proteolytic degradation in bovine, equine, and porcine preovulatory follicles: regulation by IGFs and heparin-binding domain-containing peptides. Biology of Reproduction 63 390-400.

Monget P, Fabre S, Mulsant P, Lecerf F, Elsen J-E, Mazerbourg S, Pisselet C \& Monniaux D 2002 Regulation of ovarian folliculogenesis by IGF and BMP system in domestic animals. Domestic Animal Endocrinology 23 139-154.

Nicholas B, Scougall RK, Armstrong DG \& Webb R 2002 Changes in insulin-like growth factor binding protein (IGFBP) isoforms during bovine follicular development. Reproduction 124 439-446.

O'Sullivan DC, Szestak TAM \& Pell JM 2002 Regulation of IGF-I mRNA by GH: putative functions for class 1 and 2 message. American Journal of Physiology, Endocrinology and Metabolism 283 E251-E258.

Owen EJ, Shoham Z, Mason BA, Ostergaard H \& Jacobs HS 1991 Cotreatment with growth hormone, after pituitary suppression, for ovarian stimulation in in vitro fertilization: a randomized, double-blind, placebo-control trial. Fertility and Sterility $\mathbf{5 6}$ 1104-1110.

Perks CM, Peters AR \& Wathes DC 1999 Follicular and luteal expression of insulin-like growth factors I and II and the type 1 IGF receptor in the bovine ovary. Journal of Reproduction and Fertility $116157-165$.

Rajarm S, Baylink DJ \& Mohan S 1997 Insulin-like growth factorbinding proteins in serum and other biological fluids: regulation and functions. Endocrinology Reviews 18 801-831.

Spicer LJ \& Echternkamp SE 1995 The ovarian insulin and insulinlike growth factor system with an emphasis on domestic animals. Domestic Animal Endocrinology 12 233-245.

Spicer LJ, Tucker KE, Henderson KA \& Duby RT 1991 Concentrations of insulin-like growth factor-I in follicular fluid and blood plasma of mares during early and late oestrus. Animal Reproduction Science 25 57-65.

Spicer LJ, Klindt J, Buonomo FC, Maurer R, Yen JT \& Echternkamp SE 1992 Effect of porcine somatotropin on number of granulosa cell luteinizing hormone/human chorionic gonadotropin receptors, oocyte viability, and concentrations of steroids and insulin-like growth factors-I and -II in follicular fluid of lean and obese gilts. Journal of Animal Science $\mathbf{7 0}$ 3149-3157.

Stewart RE, Spicer LJ, Hamilton TD, Keefer BE, Dawson LJ, Morgan GL \& Echternkamp SE 1996 Levels of insulin like growth factor (IGF) binding proteins, luteinizing hormone and IGF-I receptors, and steroids in dominant follicles during the first follicular wave in cattle exhibiting regular estrous cycles. Endocrinology 137 2842-2850. 
Watson ED \& Al-zi'abi MO 2002 Characterisation of morphology and angiogenesis in follicles of mares during spring transition and the breeding season. Reproduction 124 227-234.

Watson ED, Heald $M$, Tsigos A, Leask R, Steele $M$, Groome NP \& Riley SC 2002a Plasma FSH, inhibin A and inhibin isoforms containing pro- and $-\alpha \mathrm{C}$ during winter anoestrus, spring transition and the breeding season in mares. Reproduction $\mathbf{1 2 3}$ 535-542.

Watson ED, Thomassen R, Steele M, Heald M, Leask R, Groome NP \& Riley SC 2002b Concentrations of inhibin, progesterone and oestradiol in fluid from dominant and subordinate follicles from mares during spring transition and the breeding season. Animal Reproduction Science 74 55-67.

Watson ED, Bae S-E, Thomassen R, Steele $M$, Pedersen HG, Bramley T, Hogg CO \& Armstrong DG 2004 Expression of messenger ribonucleic acid encoding for steroidogenic acute regulatory protein and enzymes, and luteinizing hormone receptor during the spring transitional season in equine follicles. Domestic Animal Endocrinology 26 215-230.

Wright RJ, Jeffrey JMP, Galea R, Brincat M \& Mason HD 2002 Insulin-like growth factor (IGF)-independent effects of IGF binding protein-4 on human granulosa cell steroidogenesis. Biology of Reproduction 67 776-781.

Xu ZZ, Garverick HA, Smith GW, Smith MF, Hamilton SA \& Younquist RS 1995 Expression of messenger ribonucleic acid encoding cytochrome P450 side-chain cleavage, cytochrome P450 $17 \alpha$-hydroxylase, and cytochrome P450 aromatase in bovine follicles during the first follicular wave. Endocrinology 135 981-989.

Yuan W, Lucy M \& Smith MF 1996 Messenger ribonucleic acid for insulin-like growth factors-I and -II, insulin-like growth factor binding protein-2, gonadotropin receptors, and steroidogenic enzymes in porcine follicles. Biology of Reproduction 55 1045-1054.

Zhou J \& Bondy C 1993 Anatomy of the human ovarian insulin-like growth factor system. Biology of Reproduction 48 467-482.

Received 3 November 2003

First decision 9 January 2004

Revised manuscript received 17 March 2004

Accepted 27 May 2004 